\title{
THE CONSEQUENCES OF DIVORCE FOR ADULTS AND CHILDREN: AN UPDATE
}

Paul R. AMATO

Pennsylvania State University, University Park, PA, USA

UDK: $159.913-058.836$

613.86-058.836

364.286-056.2

Pregledni rad

Primljeno: 23. 11. 2012.

The divorce rate has increased in the United States and most European countries since the 1960s. Public and scientific concern about the consequences of divorce for adults and children has generated a large research literature. Most studies find that divorced adults experience more mental and physical health problems than do married adults. Similarly, most studies find that children with divorced parents experience more mental and physical health problems than do children with

continuously married parents. Available research suggests that these associations are partly spurious (due to selection effects) and partly due to the stress associated with marital disruption. People's reactions to divorce are highly variable, with the speed and degree of adjustment depending on a variety of resources and post-divorce circumstances. In the United States, several types of court- and community-based programs appear to facilitate parents' and children's adjustment to divorce.

Keywords: divorce, separation, mental health, physical health, effect sizes, selection, adjustment to divorce, second demographic transition

Paul R. Amato, Pennsylvania State University, Department of Sociology, 211 Oswald Tower, University Park, PA, USA, 16803. E-mail: paulamato00@gmail.com

The United States has had an unusually high rate of divorce throughout its history (Amato \& Irving, 2005). For this reason, scholarly attention to marital dissolution appeared relatively early in the American research literature. In recent decades, many European societies have also experienced marked in- 
DRUŠ. ISTRAŽ. ZAGREB GOD. 23 (2014), BR. 1, STR. 5-24

AMATO, P. R.:

THE CONSEQUENCES.. creases in divorce, and the number of studies conducted by European family scholars has increased correspondingly. Much of this research has sprung from a concern about the consequences of marital disruption for the health and wellbeing of former spouses and their children. This article provides an update and overview of research on the consequences of divorce for adults and children, with a focus on European as well as American studies.

\section{TRENDS IN THE DIVORCE RATE}

Despite the omission of data from some states, the United States Census Bureau reports the annual number of divorces per 1000 people in the population - a figure known as the crude divorce rate. This measure is less than optimal because it is affected by the age structure of the population and by the proportion of adults who are married. A better measure - the refined divorce rate - is the number of divorces per 1000 married women. Nevertheless, the two rates are highly correlated and reveal the same trends over time. Moreover, the crude divorce rate is available for a large number of nations and time periods and, hence, is useful for cross-national comparisons. ${ }^{1}$

Figure 1 shows the crude divorce rate in the United States. This rate more than doubled from 2.2 in 1960 to 5.2 in 1980. The rate dropped after the early 1980s to 3.5 in 2008 - a one third decline (United States Census Bureau, 2012). The rise in age at first marriage since the 1980s appears to be an important factor in accounting for this decline (Heaton, 2002), because people who marry at older ages have a lower risk of divorce. In addition, delaying marriage decreases the percentage of married couples in the population, thus lowering the number of individuals at risk of divorce.

FIGURE 1

The crude divorce rate in the United States

(U.S. Census Bureau,

2012)

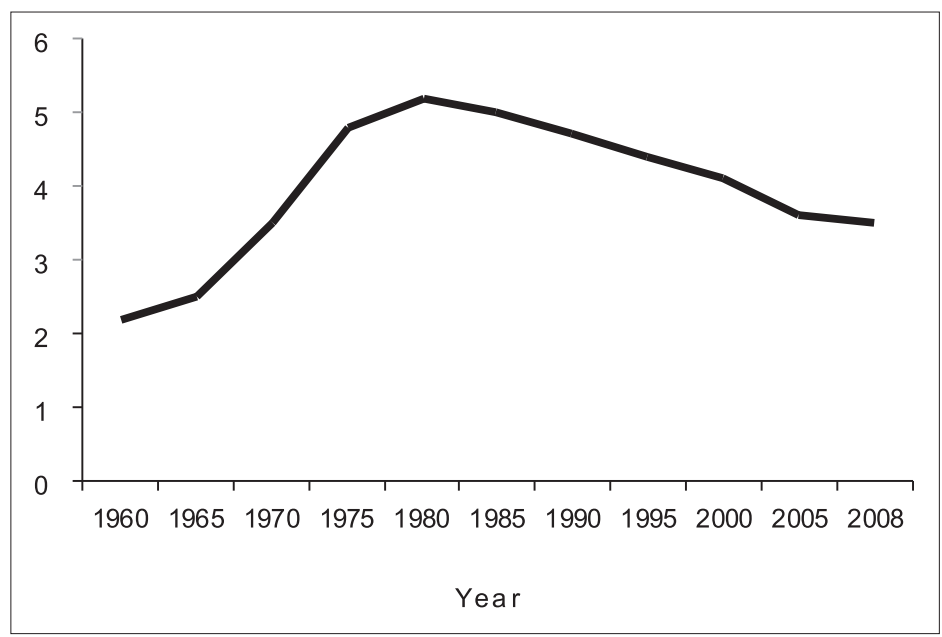


DRUŠ. ISTRAŽ. ZAGREB GOD. 23 (2014), BR. 1 STR. 5-24

AMATO, P. R. THE CONSEQUENCES...

$\ni$ FIGURE 2

The crude divorce rate in six European societies (Eurostat, 2012)
Although divorce rates are not as high in Europe as in the United States, they have been rising in recent decades. Figure 2 shows crude divorce rates for six different European nations. The figure reveals that some countries have consistently higher rates of divorce than do others. Belgium, for example, has one of the highest rates of divorce in Europe, whereas Italy has one of the lowest. Despite these differences, however, the majority of countries have shown a general increase over time. For example, between 1960 and 2010, the crude divorce rate increased from 0.5 to 3.0 in Belgium, from 0.7 to 2.1 in Norway, and from 0.3 to 1.2 in Greece (Eurostat, 2012). Figure 2 also shows that the rate of increase has slowed down, or even reversed, in some countries in recent decades. But despite these recent changes, almost all countries had a higher rate of divorce in 2010 than in 1960, including those countries in which recent declines occurred.

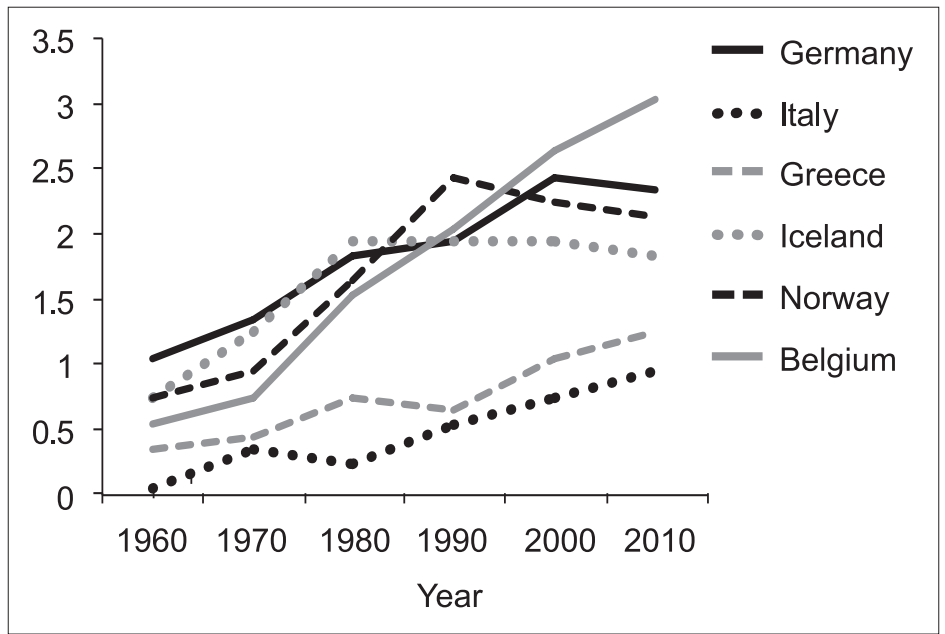

Figure 3 provides data on recent divorce rates in 2010 for a wider range of European countries. For the sake of comparison, the figure also shows the divorce rate in the United States. Note that the United States continues to have a rate of divorce larger than any European country - but not by much. Lithuania, Belgium, the Czech Republic, and Switzerland, in particular, have divorce rates only slightly lower than the United States. The figure also shows that Ireland, Montenegro, Italy, Croatia, and Greece have some of the lowest divorce rates in Europe. With a few exceptions, divorce rates tend to be lower in the southern part of Europe. (Although not shown in the figure, the average for the 27 countries in the European Union was 2.0.)

Despite variation between countries, the general upward trend means that explanations for the increase in divorce cannot be attributed to factors idiosyncratic to a particular society. Many demographers believe that the rise in divorce can be 
DRUŠ. ISTRAŽ. ZAGREB GOD. 23 (2014), BR. 1, STR. 5-24

AMATO, P. R.:

THE CONSEQUENCES...

- FIGURE 3

The crude divorce rate in the United States and various European countries, 2010

(U. S. Census Bureau

2012; Eurostat, 2012 understood within the general context of the Second Demographic Transition (SDT). The term "demographic transition" originally referred to population changes that occur as societies begin to develop economically. In most preindustrial societies, birth rates and death rates are high and in relative balance. In the early stages of economic development, death rates tend to decline due to improvements in sanitation, nutrition, health care, and education. With further development, birth rates also tend to decline due to the availability of contraception, a decrease in the value of children's labor in an urban economy, and an increase in the amount of time and money that parents invest in children. Although this model may not be universally applicable, it describes population trends in many parts of the world reasonably well.

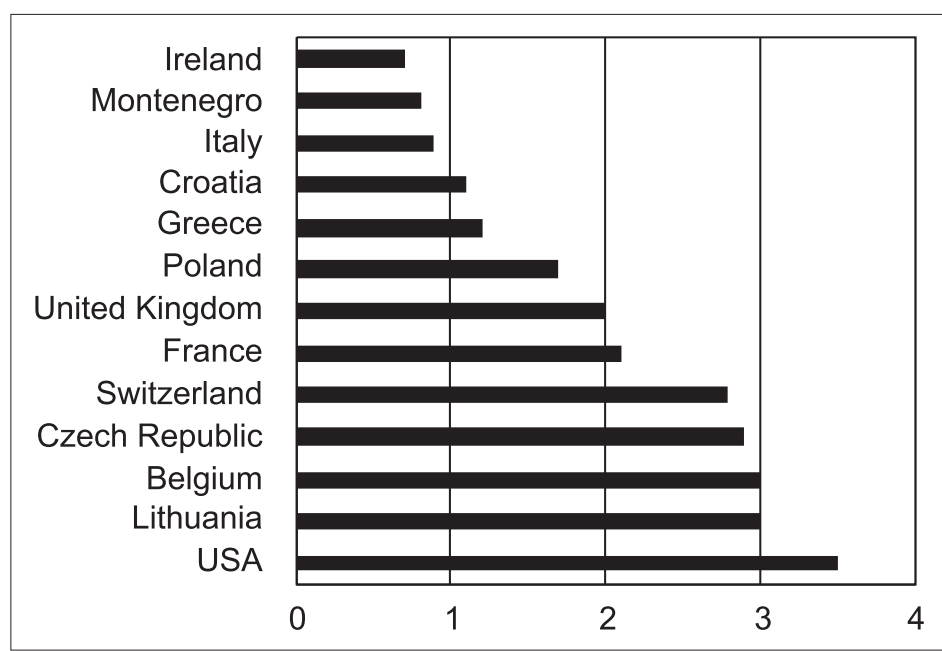

Lesthaeghe $(1983,2010)$ was one of the first social scientists to describe the SDT. According to this perspective, the various family changes observed in the West during the last century have been independent of one another. Instead, they were manifestations of a long-term shift in Western culture (or ideas and values). The major theme underlying this shift was an increase in individualism, or the freedom to seek happiness and self-fulfillment outside of traditional norms and existing social structures. Economic development led to a rise in the standard of living, which increased people's aspirations for the good life and made it possible for them to be more self-reliant. Correspondingly, the influence of larger kinship groups, social norms, and religion waned. As women's participation in the paid labor force increased, egalitarian views about gender became widespread. The growth of individualism, secularization, and egalitarianism led to a variety of family-related changes, including low-replacement fertility, rising age at marriage, and increases in nonmarital cohabitation, nonmarital births, and divorce. 
DRUŠ. ISTRAŽ. ZAGREB GOD. 23 (2014), BR. 1 STR. $5-24$

AMATO, P. R.: THE CONSEQUENCES...
The notion of a second demographic transition is related to Maslow's (1954) hierarchy of psychological needs. Maslow believed that economic development results in a shift from concerns about material needs (food, shelter, and safety) to higher-order concerns about non-material needs (freedom and self-actualization). Corresponding changes in social values also occur. In societies in which most people's physical needs are easily met, people come to value individual choice and self-expression more than allegiance to tradition and social institutions.

One reflection of this change involves parental socialization of children. In the past, parents in most Western societies emphasized the values of conformity, obedience, neatness, thriftiness, traditional gender roles, and religious faith. In recent decades, however, these values have been replaced by an emphasis on independence, autonomy, self-direction, asking questions, and creativity (Alwin, 1989). Increasingly, parents are teaching their children the values that underlie the SDT.

Until the end of the 1980s, features of the SDT were most noticeable in Northern Europe, the United States, Canada, Australia, and New Zealand (Lesthaeghe \& Neidert, 2006). Since then, family behaviors that characterize the SDT (including divorce) have become increasingly common in Central, Southern, and Eastern Europe. The SDT also is beginning to appear in a variety of Asian countries. For example, Japan, Hong Kong, South Korea and Taiwan have experienced shifts to low-replacement fertility. These same countries, along with Thailand, Singapore, Malaysia, Burma, Indonesia, and the Philippines, have shown increases in age at first marriage. In addition, nonmarital cohabitation has increased significantly in Japan and Taiwan, and divorce rates are increasing in China, Japan, and South Korea (Amato \& Boyd, in press). Overall, family trends that characterize the SDT appear to be spreading throughout much of the developed (and developing) world.

With respect to gender, research in the United States consistently shows that wives are more likely to initiate divorce than are husbands (Amato \& Previti, 2003; Hetherington \& Kelly, 2002; Kitson, 1992). This finding appears to clash with evolutionary psychology, which holds that women will stay in secure family positions for the sake of their children (Buss, 1995). Wives are especially likely to seek divorce, however, when two conditions are met: (a) they have young children and (b) their husbands are physically abusive or have substance abuse problems (Amato \& Previti, 2003). In this sense, the departure of mothers from potentially harmful marriages reflects their motivation to protect their children. Evolutionary psychology assumes that the sex that invests more in its offspring is choosier when selecting mates (Buss, 1995). It also appears to be the case that the sex that invests more in its offspring is quicker to jettison mates that prove to be poor choices. 
Many studies have compared married and currently divorced adults on various dimensions of wellbeing. In general, studies from the United States show that divorced individuals, compared with married individuals, report less happiness, more symptoms of depression, more social isolation, more negative life events, and more health problems (e.g., Bierman, Fazio, \& Milkie, 2006; Hetherington, 2003; Wood, Goesling, \& Avellar, 2007). European research also shows that divorced individuals have lower levels of health and wellbeing than do married individuals, including studies from Sweden (Gähler, 1998), Norway (Mastekaasa, 1994), Denmark (Kessing, Agerbo, \& Mortensen, 2003), Spain (Burgoa, Regidor, Rodriguez, \& Gutierrez-Fisac, 1998) and England (O'Connor, Davies, Dunn, Golding, \& the ALSPAC Study Team, 2005).

Amato (2000) proposed a straightforward model to understand why marital disruption affects most people negatively. According to this model, divorce should be viewed, not as a discrete event, but as a process that unfolds over months and even years. During this time, a variety of stressful life events typically occur. These stressors include a decline in the standard of living, which generally results from splitting one household into two and losing economies of scale. Formerly married individuals often move following divorce, and this is a time consuming and stressful experience for many people. Parents who retain primary custody of children (usually mothers) often experience the strain of solo parenting, given that a second parent is no longer present in the household to share daily childrearing tasks. Correspondingly, nonresident parents (usually fathers) often find the loss of daily contact with their children to be distressing. Because married couples tend to socialize with other married couples, newly divorced adults often find that they drift apart from former friends. Finally, conflict can continue between former parents over issues of child residence and access. All of these stressful features of divorce can take a cumulative toll on people's physical and mental health (Graham, Christian, \& Kiecolt-Glaser, 2006).

Divorce also means the loss of benefits associated with marriage. For many people, marriage provides emotional support, companionship, a regular sexual partner, and economic security. Moreover, spouses often encourage one another to adopt healthier lifestyles and minimize potentially harmful behaviors, such as excessive alcohol use or smoking. In other words, divorce involves both a negative factor (more stress) and the loss of a positive factor (the beneficial effects of marriage). In fact, studies show that the general health and wellbeing of the divorced (once they have moved through the ini- 
DRUŠ. ISTRAŽ. ZAGREB GOD. 23 (2014), BR. 1 STR. 5-24

AMATO, P. R.: THE CONSEQUENCES... tial crisis period) does not differ markedly from that of the never married or the widowed - a pattern that holds for women as well as men (e.g., Rendall, Weden, Favreault, \& Waldron, 2011). Consequently, many of the disadvantages associated with being divorced appear to reflect the absence of a stable, committed, and satisfying intimate relationship.

The stressful circumstances associated with marital dissolution tend to diminish with the passage of time for most adults, and successful adjustment often involves the adoption of new roles (Hetherington \& Kelly, 2002). Some former wives decide to increase their educational qualifications following divorce. Other former wives return to the labor force. Most divorced individuals eventually make new friends and establish new romantic relationships. Successful adjustment also requires people to develop new identities that no longer are bound up with the former marriage (Amato, 2000).

Although most people eventually recover from divorcerelated stress, the speed of recovery depends on people's access to resources. Resources include having an adequate income, a high level of education, support from kin and friends, and support from new romantic partners. Resources that reside in the individual, such as good coping and social skills, also are important. The speed of adjustment also depends on the meanings that people attribute to divorce. Some individuals view divorce as a tragedy and a personal failing, whereas other individuals view the divorce - although stressful - as an opportunity for a new beginning and for personal growth. Not surprisingly, holding positive views about divorce is more common among spouses who initiate divorce than among spouses who are left behind (Wang \& Amato, 2000).

In general, people with a high level of resources and who interpret the divorce in positive terms tend to adjust relatively quickly (Amato, 2000).

As noted earlier, wives are more likely than husbands to initiate divorce. For this reason, former wives tend to show better emotional adjustment than do former husbands in the first year following divorce (Hetherington \& Kelly, 2002). Of course, this also means that wives experience more distress than do husbands prior to divorce, as they mourn the unraveling and impending loss of their marriages.

A selection perspective provides a different way of understanding divorce. According to this perspective, many individuals bring traits to their marriages that increase the risk of marital disruption as well as personal problems. For example, people with antisocial personality traits, neurotic personalities, a tendency to depression, and poor relationship are likely to experience low marital quality and see their marria- 
DRUŠ. ISTRAŽ. ZAGREB STR. 5-24

AMATO, P. R. THE CONSEQUENCES... GOD. 23 (2014), BR. 1,

ges end in divorce (Kearney \& Bradbury, 1995). Indeed, for many people, problems with psychological adjustment can be causes rather than consequences of divorce.

A number of studies have attempted to distinguish between selection and divorce causation (stress) perspectives. Some researchers have used fixed effects statistical models that control for all time-invariant differences between divorced and married individuals. These studies suggest that some of the differences between these groups are due to selection and other differences are due to divorce causation. For example, Wade and Pevalin (2004) found that individuals in the United States who separated or divorced had poorer mental health prior to marital disruption - a finding consistent with a selection perspective. Mental health decreased even more following divorce, however - a finding consistent with the notion that the stress of divorce further erodes people's mental health. Similarly, Johnson and $\mathrm{Wu}$ (2002) found that spouses headed for divorce had an elevated level of psychological distress many years prior to separation. Following disruption, however, levels of distress increased even more. Moreover, distress tended to remain elevated until people remarried, after which it declined. Other studies that support the notion that divorce brings about declines in mental and physical health net of selection come from the United States (e.g., Simon, 2002) as well as Europe (e.g., Brockmann \& Klein, 2004).

On a more general level, it is likely that the stress of divorce has abated to a certain extent as divorce has become more common. In the past, when divorce was highly stigmatized, the consequences of marital disruption were almost certainly more severe than they are today - a conclusion that presumably holds for children as well as adults. Few researchers have tested this hypothesis directly, although some data on the intergenerational transmission of divorce support this notion (Wolfinger, 1999, 2011; but see Li and Wu, 2008 for contrary evidence).

\section{DIVORCE AND CHILDREN'S WELL-BEING}

A large number of studies from the United States have compared children with divorced and continuously married parents on a variety of outcomes. Several scholars, including Amato (2000, 2001), Hetherington and Kelly (2002), and Kelly and Emery (2003), have reviewed this (primarily) American research literature. Rodgers and Pryor (1998) reviewed comparable studies from England, Canada, Australia, and New Zealand. In general, the accumulated research shows that children with divorced parents, compared with children with continuously married parents, exhibit more conduct problems, have 
DRUŠ. ISTRAŽ. ZAGREB GOD. 23 (2014), BR. 1 STR. 5-24

AMATO, P. R.: THE CONSEQUENCES... more emotional problems, obtain lower academic test scores and school grades, and have more problems with social relationships. Divorce also is associated with weaker emotional ties with parents - especially fathers. These disadvantages appear to persist into adulthood. In particular, individuals who experienced parental divorce, compared with individuals who grew up with continuously married parents, obtain less education, earn less income, are more likely to have nonmarital births, are at greater risk of becoming depressed, and have poorer physical health. In addition, individuals who experienced parental divorce while growing up report more problems in their own marriages and are more likely to see their marriages end in disruption.

European research on children and divorce, although less common, is generally in agreement with studies conducted in the United States and other English-speaking countries. Table 1 provides a brief summary of this research. Studies that have focused on behavioral and emotional problems come from Bulgaria, the Netherlands, Greece, Germany, and Norway. Studies of educational achievement come from Italy and Sweden. Studies looking at health problems, substance use (alcohol and tobacco), and risky sexual behavior come from Germany, France, Greece, the Netherlands, and Slovakia. Two studies from Denmark focused on delinquent activities, and a study from Germany examined attachment security.

Almost all of these studies found that children with divorced parents had poorer outcomes, on average, than did children with continuously married parents. One way of summarizing these findings is to use the methods of meta-analysis and translate each study result into an effect size. For a particular child outcome (the dependent variable), the effect size is defined as the mean for the two-parent group minus the mean for the divorced group, divided by the pooled standard deviation. The effect size reveals the difference between the two groups of children in standard deviation units. Because all outcomes are expressed on a common metric (standard deviation units), it is possible to combine results across studies. (See Rosenthal, 1994, for information on the calculation of effect sizes.)

The studies listed in Table 1 yielded a total of 55 effect sizes. Averaging across all types of outcomes, the mean effect size was -0.30 (S.E. $=0.02, p<0.001,95 \%$ confidence interval $=-0.34$ through -0.25$)$. In other words, the typical study found that children with divorced parents scored 0.3 of a standard deviation below children with continuously married parents on some measure of wellbeing. Effect sizes did not vary dramatically across outcomes and ranged from -0.23 (S.E. $=0.04$, $p<0.001)$ for measures of academic achievement to -0.38 (S. E. $=0.04, p<0.001)$ for measures of internalizing problems. 


\begin{tabular}{|c|c|c|c|}
\hline Author(s) (Year) & Country & Sample sizes & Outcomes \\
\hline Albertini and Dronkers (2009) & Italy & $\begin{array}{l}723 \text { (divorce) } \\
18233 \text { (no divorce) }\end{array}$ & Educational attainment \\
\hline Bockelbrink et al. (2006) & Germany & $\begin{array}{l}65 \text { (divorce) } \\
1844 \text { (no divorce) }\end{array}$ & $\begin{array}{l}\text { Prevalence and incidence of } \\
\text { atopic eczema }\end{array}$ \\
\hline $\begin{array}{l}\text { Challier, Chau, Prédine, } \\
\text { Choquet, and Legras (2000) }\end{array}$ & France & $\begin{array}{l}764 \text { (divorce) } \\
1632 \text { (no divorce) }\end{array}$ & Tobacco use (smoking) \\
\hline Christopoulos (2001) & Bulgaria & $\begin{array}{l}50 \text { (divorce) } \\
50 \text { (no divorce) }\end{array}$ & Psychological problems \\
\hline Dronkers (1999) & The Netherlands & $\begin{array}{l}681 \text { (divorce) } \\
9135 \text { (no divorce) }\end{array}$ & $\begin{array}{l}\text { Well-being (drug use, crime, } \\
\text { school problems, depression, } \\
\text { suicidal thoughts) }\end{array}$ \\
\hline $\begin{array}{l}\text { Gloger-Tippelt } \\
\text { and König (2007) }\end{array}$ & Germany & $\begin{array}{l}60 \text { (divorce) } \\
51 \text { (no divorce) }\end{array}$ & Parent-child attachment style \\
\hline Hatzichristou (1993) & Greece & $\begin{array}{l}26 \text { (divorce) } \\
381 \text { (no divorce) }\end{array}$ & $\begin{array}{l}\text { Behavior problems, depression, } \\
\text { school performance }\end{array}$ \\
\hline Jonsson and Gähler (1997) & Sweden & $\begin{array}{l}22393 \text { (divorce) } \\
96718 \text { (no divorce) }\end{array}$ & School continuation \\
\hline $\begin{array}{l}\text { Ledoux, Miller, Choquet, } \\
\text { and Plant (2002) }\end{array}$ & France & $\begin{array}{l}249 \text { (divorce) } \\
1660 \text { (no divorce) }\end{array}$ & $\begin{array}{l}\text { Tobacco, marijuana, or illicit } \\
\text { drug use }\end{array}$ \\
\hline $\begin{array}{l}\text { Mednick, Baker, } \\
\text { and Carothers (1990) }\end{array}$ & Denmark & $\begin{array}{l}116 \text { (divorce) } \\
292 \text { (no divorce) }\end{array}$ & Recorded criminal charges \\
\hline $\begin{array}{l}\text { Mednick, Reznick, Hocevar, } \\
\text { and Baker (1987) }\end{array}$ & Denmark & $\begin{array}{l}102 \text { (divorce) } \\
241 \text { (no divorce) }\end{array}$ & Juvenile arrests \\
\hline Spruijt and Duindam (2010) & The Netherlands & $\begin{array}{l}148 \text { (divorce) } \\
1089 \text { (no divorce) }\end{array}$ & $\begin{array}{l}\text { Risky habits, number of } \\
\text { sex partners }\end{array}$ \\
\hline $\begin{array}{l}\text { Steinhausen, von Aster, } \\
\text { and Göbel (1987) }\end{array}$ & Germany & $\begin{array}{l}121 \text { (divorce) } \\
252 \text { (no divorce) }\end{array}$ & Conduct disorder, neurosis \\
\hline $\begin{array}{l}\text { Størksen, Røysamb, Moum, } \\
\text { and Tambs (2005) }\end{array}$ & Norway & $\begin{array}{l}413 \text { (divorce) } \\
758 \text { (no divorce) }\end{array}$ & $\begin{array}{l}\text { Anxiety/depression, subjective } \\
\text { well-being, self-esteem, school } \\
\text { problems }\end{array}$ \\
\hline $\begin{array}{l}\text { Størksen, Røysamb, Holmen, } \\
\text { and Tambs (2005) }\end{array}$ & Norway & $\begin{array}{l}1810 \text { (divorce) } \\
6784 \text { (no divorce) }\end{array}$ & $\begin{array}{l}\text { Anxiety/depression, subjective } \\
\text { well-being, school problems }\end{array}$ \\
\hline $\begin{array}{l}\text { Tomcikova, Geckova, Orosova, } \\
\text { van Dijk, and Reijneveld ( } 2009)\end{array}$ & Slovakia & $\begin{array}{l}723 \text { (divorce) } \\
2815 \text { (no divorce) }\end{array}$ & Recent drunkenness \\
\hline Yannakoulia et al. (2008) & Greece & $\begin{array}{l}96 \text { (divorce) } \\
1002 \text { (no divorce) }\end{array}$ & Eating style \\
\hline
\end{tabular}

(1) TABLE 1

European studies that compared children with divorced and continuously married parents
Studies vary in sample size, and larger samples yield more precise estimates of effect sizes in the population than do smaller samples (Shadish \& Haddock, 1994). Weighting the effect sizes to account for sample size revealed a mean effect size across all studies of -0.17 (S.E. $=0.05, p<0.001,95 \%$ C.I. $=-0.27$ through $-0.07)$. This result indicates that larger studies tended to yield weaker effect sizes than did smaller studies. In general, effect sizes in the range produced by European studies (a quarter to a third of a standard deviation) are moderate in magnitude but large enough to be nontrivial. 
DRUŠ. ISTRAŽ. ZAGREB GOD. 23 (2014), BR. 1 STR. 5-24

AMATO, P. R.: THE CONSEQUENCES...
How do the effect sizes from European studies compare with the effect sizes generated by American research? Amato (2001) reported the results of a meta-analysis that focused on studies of children and divorce conducted in the United States during the 1990s. His analysis found that the average unweighted effect size (across all studies) was -0.29 , and the average weighted effect size was -0.18 . In other words, the overall effect sizes from American and European studies are nearly identical. Irrespective of national and cultural characteristics, the gap between children with divorced and continuously married parents is about the same on both sides of the Atlantic.

Other European studies suggest that the consequences of parental divorce persist into adulthood. For example, the trend for offspring with divorced parents to see their own marriages end in dissolution (the intergenerational transmission of divorce) has been shown in countries as diverse as Belgium, the Czech Republic, Estonia, Finland, Germany, Greece, Hungary, Italy, Latvia, Lithuania, the Netherlands, Sweden, Switzerland, and the United Kingdom (Dronkers \& Härkönen, 2008; Wagner \& Weiß, 2006). The Wagner and Weiß (2006) study found that the intergenerational effect was strongest in the Netherlands and Italy and weakest in Austria and Finland. They also found that the intergenerational transmission of divorce was weaker in countries where divorce was more common. Although this finding was cross-national rather than historical, it suggests that as divorce becomes more accepted, the elevated risk of marital disruption for adult children of divorce declines.

Similar to adults who experience divorce, the associations between parental divorce and negative psychological, social, and health outcomes among children appear to be partly spurious (due to selection effects) and partly causal. That is, children with divorced parents appear to be disadvantaged partly because their parents brought risky traits to their marriages (e.g., problematic personality traits, poor relationship skills) and partly because divorce itself is harmful to many children. (For a review of this evidence, see Amato, 2010). The average estimated effect of divorce on children is moderate rather than strong, however. This is because children react to parental divorce in a variety of ways, with some but not others showing clear signs of maladjustment.

Several resources and protective factors have been shown to moderate the link between divorce and problematic child outcomes. First, children adjust more easily if their standard of living does not decline precipitously in the post-divorce years. Children's adjustment also depends on how well their parents have adjusted to the disruption. When parents con- 
DRUŠ. ISTRAŽ. ZAGREB GOD. 23 (2014), BR. 1, STR. 5-24

AMATO, P. R.: THE CONSEQUENCES.. front long-term feelings of loss or anger, their negative moods can "spill over" and affect their children. Moreover, all children (including children of divorce) benefit when their parents engage in authoritative parenting - a parenting style that combines emotional support and responsiveness to children's needs with firmness, high expectations, and ongoing supervision. Children also do better if their parents are able to maintain positive co-parental relationships in the post-divorce years, despite the complications of living in separate households. It is particularly important that parents not involve their children in disputes over children's living arrangements, visitation, and child support. In general, children thrive on stability. For this reason, they tend to be better adjusted if they are able to remain in the same neighborhoods and schools following divorce. Finally, parents need to be careful not to introduce their new romantic partners into children's lives too soon. Children can form close bonds with parents' partners and stepparents, but only when they have had sufficient time to establish new norms, boundaries, and relationships with these individuals. (For reviews of factors that facilitate children's adjustment to divorce, see Amato, 2000; Hetherington \& Kelly, 2002; and Kelly \& Emery, 2003.)

These considerations reveal why children's responses to marital disruption are so variable. Consider two young children with divorced parents. One child experiences a sharp decline in standard of living following parental separation. To stay within budget, the mother and child move from their home into a smaller apartment in a less desirable part of town. The child's mother (the primary residential parent) began to experience symptoms of depression shortly before the breakup, and this affects her ability to interact with her child in a warm and supportive way. Moreover, she tends to ignore her child much of the time, only to explode in a harsh and punitive manner when the child misbehaves. The child's father has relatively little contact with his child, and on those occasions when the father visits, he engages in loud, angry conflict with the mother. Much of the fighting is about the child, which makes the child feel responsible for what is happening. Despite the mother's depression, she has formed a relationship with another man. Although the new boyfriend occasionally spends the night with the mother, he does not interact much with the child. Given this constellation of factors, we would not be surprised to learn that the child is exhibiting a variety of serious symptoms of maladjustment.

The second child experiences a decline in standard of living, but the decline is not so serious that it requires moving out of the family home. Despite the mother's sadness at the 
DRUŠ. ISTRAŽ. ZAGREB GOD. 23 (2014), BR. 1 STR. 5-24

AMATO, P. R. THE CONSEQUENCES... end of the marriage, she also views the divorce as an opportunity to have a better life. Moreover, she is able to focus on her child's needs (rather than her own) and maintains a firm but loving home environment. The father spends time with the child every week, and the two have maintained a close relationship. Moreover, although the mother and father hold some negative feelings about one another, they are able to set aside their disagreements and cooperate for the sake of the child. As a result, the child experiences similar routines and rules in the mother's and the father's households. Although both parents assume that they will form new relationships, they are waiting until they and the child have had a chance to adapt to new post-divorce realities before adding further complications to their lives. Given this particular constellation of factors, we would not be surprised to learn that the child is adjusting well to the divorce. Divorce is not a uniform experience for children, and the diversity of circumstances surrounding marital disruption means that children's reactions reveal a great deal of diversity.

\section{PROGRAMS AND POLICIES FOR DIVORCING FAMILIES}

Some research in the United States has examined programs and interventions for helping parents and children cope with divorce. For example, divorce education classes for parents have become increasingly common in recent decades. Currently, about half of all American court systems refer parents to court- or community-based education programs. These courses vary in content and length, but most are designed to inform parents about steps they can take to minimize the potentially detrimental effects of divorce on children. Some states mandate these courses for all divorcing parents with minor children, whereas other states make them optional. These courses vary in length from 90 minutes to a half day and are taught by individuals with backgrounds in family law, child welfare, or family studies.

Studies indicate that most parents find these classes to be useful, even when attendance is mandatory (Geasler \& Blaisure, 1998). One study found that men and women who attended divorce education classes reported less conflict with their former spouses and were less likely to return to court to resolve disagreements (Criddle, Allgood, \& Piercy, 2003). Another study found that mothers who attended divorce education classes reported more positive family functioning, fewer symptoms of psychological distress, and better divorce adjustment (Zimmerman, Brown, \& Portes, 2004). Unfortunately, we do not know whether these courses directly benefit children. Ne- 
DRUŠ. ISTRAŽ. ZAGREB GOD. 23 (2014), BR. 1, STR. 5-24

AMATO, P. R.

THE CONSEQUENCES.. vertheless, these courses appear to be useful to parents and are not prohibitively expensive to implement.

A related approach involves community-based programs for children, often located in schools. Many courts in the United States refer children to these programs, although attendance is usually voluntary. These programs aim to provide children with social support, encourage children to talk about their feelings, reduce feelings of isolation, develop coping skills, and generally help children adjust to their new circumstances. These sessions can vary in length from a few hours to 10 weeks or longer (Geelhoed, Blaisure, \& Geasler, 2001). Researchers have conducted several evaluations of these programs, and most have found positive effects on children, including reductions in negative feelings about the divorce, reductions in school-related problems, and increased feelings of competence (Pedro-Carroll, 2005).

Another approach is reflected in the growing popularity of divorce mediation. Mediation is a conflict resolution method that helps parents resolve disagreements over issues such as child custody, access arrangements, property division, and child support. Parents meet with trained mediators for several hour-long sessions, usually lasting from six to nine hours. Mediators may have training in psychotherapy, counseling, law, or conflict resolution. Sometimes mediators also meet with children. Unlike divorce education classes, mediation is individually tailored for the needs and concerns of specific couples. The key assumption underlying mediation is that if both parents are satisfied with the final agreement, then they will be more likely to cooperate following divorce. For couples with disputes, mediation is now mandatory - or can be made mandatory at the discretion of the judge - in the majority of American states.

In a review of the literature on mediation, Kelly (2004) reported that couples reach agreement between one half and three fourths of the time. Evaluation studies indicate that mediation decreases the likelihood that couples will pursue litigation, lowers the cost of divorce, and increases parents' satisfaction with the final outcome (Douglas, 2006). Emery and colleagues (Emery, Sbarra, \& Grover, 2005) conducted the most rigorous study of mediation by randomly assigning couples to mediation and nonmediation groups and following these parents for over a decade. These researchers found that mediation resulted in greater satisfaction with postdivorce outcomes, more contact between nonresident fathers and children, and better communication and less conflict between divorced parents. 
High divorce rates have become a fact of life in most developed, western societies. Although divorce rates have declined slightly in recent years in some countries, we are unlikely to go back to the low levels of divorce that characterized the past. Although people often lament this trend, we should keep in mind that in the past, many continuously married couples were not particularly happy. The general availability of divorce has made it easier for people to leave dysfunctional or abusive marriages and seek greater happiness and fulfillment with more compatible partners. It makes little sense to return to a time in which marital dissolution was difficult to obtain and divorced individuals were scorned and stigmatized. Nevertheless, divorce introduces a great deal of stress into the lives of adults and children, and programs and interventions to ease the strain of marital disruption, especially for families with children, are worth implementing.

\section{NOTES}

1 Calculations indicate that correlation between the crude divorce rate and the refined divorce rate in the United States between 1955 and 2005 was 0.96 . Moreover, both rates revealed similar trends over time. Refined divorce rates for most of the countries shown in Figure 3 , have also been calculated, although not always for the same year (2010). The correlation between the crude and refined divorce rates was 0.98 , and both rates revealed similar differences between countries. These calculations indicate that despite some limitations, the crude divorce rate is a reasonable substitute for the refined divorce rate for general comparisons.

\section{REFERENCES}

Albertini, M., \& Dronkers, J. (2009). Effects of divorce on children's educational attainment in a Mediterranean and Catholic society. European Societies, 11(1), 137-159. doi:10.1080/14616690802248042

Alwin, D. F. (1989). Changes in qualities valued in children in the United States, 1964 to 1984. Social Science Research, 18(3), 195-236. doi:10. 1016/0049-089X(89)90005-7

Amato, P. R. (2000). The consequences of divorce for adults and children. Journal of Marriage and Family, 62(4), 1269-1287. doi:10.1111/j.17413737.2000.01269.x

Amato, P. R. (2001). Children of divorce in the 1990s: An update of the Amato and Keith (1991) meta-analysis. Journal of Family Psychology, 15(3), 355-370. doi:10.1037/0893-3200.15.3.355

Amato, P. R. (2010). Research on divorce: Continuing trends and new developments. Journal of Marriage and Family, 72(3), 650-666. doi:10. 1111/j.1741-3737.2010.00723.x

Amato, P. R., \& Boyd, L. (in press). Children and divorce in world perspective. In A. Abela, \& J. Walker (Eds.), Contemporary issues in family 
DRUŠ. ISTRAŽ. ZAGREB GOD. 23 (2014), BR. 1, STR. 5-24

AMATO, P. R.

THE CONNEQUENCES.. studies: Global perspectives on partnerships, parenting and support in a changing world. London: Wiley-Blackwell.

Amato, P. R., \& Irving, S. (2005). A historical perspective on divorce in the United States. In M. Fine, \& J. Harvey (Eds.), Handbook of divorce and relationship dissolution (pp. 41-58). Hillsdale, NJ: Lawrence Erlbaum.

Amato, P. R., \& Previti, D. (2003). People's reasons for divorcing: Gender, social class, the life course, and adjustment. Journal of Family Issues, 24(5), 602-626. doi:10.1177/0192513X03024005002

Bierman, A., Fazio, E. M., \& Milkie, M. A. (2006). A multifaceted approach to the mental health advantage of the married: Assessing how explanations vary by outcome measure and unmarried group. Journal of Family Issues, 27(4), 554-582. doi:10.1177/0192513X05284111

Bockelbrink, A., Heinrich, J., Schäfer, I., Zutavern, A., Borte, M., et al. (2006). Atopic eczema in children: Another harmful sequel of divorce. Allergy, 61(12), 1397-1402. doi:10.1111/j.1398-9995.2006.01186.x

Brockmann, H., \& Klein, T. (2004). Love and death in Germany: The marital biography and its effect on mortality. Journal of Marriage and the Family, 66(3), 567-581. doi:10.1111/j.0022-2445.2004.00038.x

Burgoa, M., Regidor, E., Rodriguez, C., \& Gutierrez-Fisac, J. L. (1998). Mortality by cause of death and marital status in Spain. European Journal of Public Health, 8(1), 37-42. doi:10.1093/eurpub/8.1.37

Buss, D. M. (1995). Psychological sex-differences: Origins through sexual selection. American Psychologist, 50(3), 164-168. doi:10.1037/ 0003-066X.50.3.164

Challier, B., Chau, N., Prédine, R., Choquet, M., \& Legras, B. (2000). Associations of family environment and individual factors with tobacco, alcohol, and illicit drug use in adolescents. European Journal of Epidemiology, 16(1), 33-42. doi:10.1023/A:1007644331197

Christopoulos, A. L. (2001). Relationships between parent's marital status and university students' mental health. Views of mothers and views of fathers: A study in Bulgaria. Journal of Divorce $\mathcal{E}$ Remarriage 34(3-4), 179-190. doi:10.1300/J087v34n03_11

Criddle, M. N., Allgood, S. M., \& Piercy, K. W. (2003). The relationship between mandatory divorce education and level of post-divorce parental conflict. Journal of Divorce \& Remarriage, 39(3-4), 99-111. doi:10.1300/J087v39n03_05

Douglas, E. M. (2006). Mending broken families: Social policies for divorced families. Lanham, MD: Rowman \& Littlefield.

Dronkers, J. (1999). The effects of parental conflicts and divorce on the well-being of pupils in Dutch secondary education. European Sociological Review, 15(2), 195-212. doi:10.1093/oxfordjournals.esr.a018260

Dronkers, J., \& Härkönen, J. (2008). The intergenerational transmission of divorce in cross-national perspective: Results from the fertility and family surveys. Population Studies, 62(3), 273-288. doi:10.1080/ 00324720802320475

Emery, R. E., Sbarra, D. A., \& Grover, T. (2005). Divorce mediation: Research and reflections. Family Court Review, 43(1), 22-37. doi:10.1111/ j.1744-1617.2005.00005.x

Eurostat (2012). Marriage and Divorce Statistics. http://epp.eurostat.ec.euro pa.eu/statistics_explained/index.php/Marriage_and_divorce_sta tistics. 
DRUŠ. ISTRAŽ. ZAGREB GOD. 23 (2014), BR. 1 STR. 5-24

AMATO, P. R. THE CONSEQUENCES..
Gähler, M. (1998). Life after divorce: Economic, social and psychological well-being among Swedish adults and children following family dissolution. Stockholm: Swedish Institute for Social Research.

Geasler, M. J., \& Blaisure, K. R. (1998). A review of divorce education program materials. Family Relations, 47(2), 167-175. doi:10.2307/585621

Geelhoed, R. J., Blaisure, K. R., \& Geasler, M. J. (2001). Status of courtconnected programs for children whose parents are separating or divorcing. Family Court Review, 39(4), 393-404. doi:10.1111/j.174-1617. 2001.tb00621.x

Gloger-Tippelt, G., \& König, L. (2007). Attachment representations in 6-year-old children from one and two parent families in Germany. School Psychology International, 28(3), 313-330. doi:10.1177/014303430 7078540

Graham, J. E., Christian, L. M., \& Kiecolt-Glaser, J. K. (2006). Stress, age, and immune function: Toward a lifespan approach. Journal of Behavioral Medicine, 29(4), 389-400. doi:10.1007/s10865-006-9057-4

Hatzichristou, C. (1993). Children's adjustment after parental separation: Teacher, peer, and self-report in a Greek sample: A research note. Journal of Child Psychology and Psychiatry, 34(8), 1469-1478. doi:10.1111/j.1469-7610.1993.tb02104.x

Heaton, T. B. (2002). Factors contributing to increasing marital stability in the United States. Journal of Family Issues, 23(3), 392-409. doi:10. 1177/0192513X02023003004

Hetherington, E. M. (2003). Intimate pathways: Changing patterns in close personal relationships across time. Family Relations, 52(4), 318-331. doi:10.1111/j.1741-3729.2003.00318.x

Hetherington, E. M., \& Kelly, J. (2002). For better or for worse: Divorce reconsidered. New York: Norton.

Johnson, D. R., \& Wu, J. (2002). An empirical test of crisis, social selection, and role explanations of the relationship between marital disruption and psychological distress: A pooled time-series analysis of four-wave panel data. Journal of Marriage and Family, 64(1), 211-224. doi:10.1111/j.1741-3737.2002.00211.x

Jonsson, J. O., \& Gähler, M. (1997). Family dissolution, family reconstitution, and children's educational careers: Recent evidence for Sweden. Demography, 34(2), 277-293. doi:10.2307/2061705

Kearney, B. R., \& Bradbury, T. N. (1995). The longitudinal course of marital quality and stability: A review of theory, method, and research. Psychological Bulletin, 118(1), 3-34. doi:10.1037/0033-2909.118.1.3

Kelly, J. B. (2004). Family mediation research: Is there empirical support for the field? Conflict Resolution Quarterly, 22(1-2), 3-35. doi:10. 1002/crq.90

Kelly, J. B., \& Emery, R. E. (2003). Children's adjustment following divorce: Risk and resilience perspectives. Family Relations, 52(4), 352-362. doi:10.1111/j.1741-3729.2003.00352.x

Kessing, L. V., Agerbo, E., \& Mortensen, P. B. (2003). Does the impact of major stressful life events on the risk of developing depression change throughout life? Psychological Medicine, 33(7), 1177-1184. doi:10.1017/ S0033291703007852 
DRUŠ. ISTRAŽ. ZAGREB GOD. 23 (2014), BR. 1, STR. $5-24$

AMATO, P. R.

THE CONSEQUENCES..
Kitson, G. C. (1992). Portrait of divorce: Adjustment to marital breakdown. New York: Guilford.

Ledoux, S., Miller, P., Choquet, M., \& Plant, M. (2002). Family structure, parent-child relationships, and alcohol and other drug use among teenagers in France and the United Kingdom. Alcohol and Alcoholism, 37(1), 52-60. doi:10.1093/alcalc/37.1.52

Lesthaeghe, R. (1983). A century of demographic and cultural change in Western Europe: An exploration of underlying dimensions. Population and Development Review, 9(3), 411-435. doi:10.2307/1973316

Lesthaeghe, R., \& Neidert, L. (2006). The second demographic transition in the United States: Exception or textbook example? Population and Development Review, 32(4), 669-698. doi:10.1111/j.1728-4457.2006.00146.x

Lesthaeghe, R. (2010). The unfolding story of the second demographic transition. Population and Development Review, 36(2), 211-251. doi:10.1111/j.1728-4457.2010.00328.x

Li, J., \& Wu, L. L. (2008). No trend in the intergenerational transmission of divorce. Demography, 45(4), 875-883. doi:10.1353/dem.0.0030

Maslow, A. (1954). Motivation and personality. New York: Harper \& Row.

Mastekaasa, A. (1994). The subjective well-being of the previously married: The importance of unmarried cohabitation and time since widowhood or divorce. Social Forces, 73(2), 665-692. doi:10.1093/sf/73.2.665 Mednick, B., Baker, R., \& Carothers, L. (1990). Patterns of family instability and crime: The association of timing of the family's disruption with subsequent adolescent and young adult criminality. Journal of Youth and Adolescence, 19(3), 201-219. doi:10.1007/BF01537887

Mednick, B., Reznick, C., Hocevar, D., \& Baker, R. (1987). Long-term effects of parental divorce on young adult male crime. Journal of Youth and Adolescence, 16(1), 31-45. doi:10.1007/BF02141545

O'Connor, T. G., Davies, L., Dunn, J., Golding, J., \& the ALSPAC Study Team (2000). Distribution of accidents, injuries, and illnesses by family type. Pediatrics, 106(5), 1-6. doi:10.1542/peds.106.5.e68

Pedro-Carroll, J. L. (2005). Fostering resilience in the aftermath of divorce: The role of evidence-based programs for children. Family Court Review, 43(1), 52-64. doi:10.1111/j.1744-1617.2005.00007.x

Rendall, M. S., Weden, M. M., Fabreault, M. M., \& Waldron, H. (2011) The protective effect of marriage for survival: A review and update. Demography, 48(2), 481-506. doi:10.1007/s13524-011-0032-5

Rodgers, B., \& Pryor, J. (1998). Divorce and separation: The outcomes for children. London: Joseph Rowntree Foundation.

Rosenthal, R. (1994). Parametric measures of effect size. In H. Cooper, \& L. V. Hedges (Eds.), The handbook of research synthesis (pp. 231-244). New York: Russell Sage.

Shadish, W. R., \& Haddock, C. K. (1994). Combining estimates of effect size. In H. Cooper, \& L. V. Hedges (Eds.), The handbook of research synthesis (pp. 261-284). New York: Russell Sage.

Simon, R. W. (2002). Revisiting the relationship among gender, marital status, and mental health. American Journal of Sociology, 107(4), 1065-1096. doi:10.1086/339225 
DRUŠ. ISTRAŽ. ZAGREB GOD. 23 (2014), BR. 1, STR. 5-24

AMATO, P. R. THE CONSEQUENCES...
Spruijt, E., \& Duindam, V. (2010). Problem behavior of boys and young men after parental divorce in the Netherlands. Journal of Divorce and Remarriage, 43(3), 141-155.

Steinhausen, H. C, Von Aster, S., \& Göbel, D. (1987). Family composition and child psychiatric disorders. Journal of the American Academy of Child E Adolescent Psychiatry, 26(2), 242-247. doi:10.1097/00004583198703000-00022

Størksen, I., Røysamb, E., Holmen,T. L., \& Tambs, K. (2006). Adolescent adjustment and well-being: Effects of parental divorce and distress. Scandinavian Journal of Psychology, 47(1), 75-84. doi:10.1111/j.1467-9450.2006. 00494.x

Størksen, I., Røysamb, E., Moum, T., \& Tambs, K. (2005). Adolescents with a childhood experience of divorce: A longitudinal study of mental health and adjustment. Journal of Adolescence, 28(6), 725-739. doi:10. 1016/j.adolescence.2005.01.001

Tomcikova, Z., Geckova, A., Orosova, O., Van Dijk, J. P., \& Reijneveld, S. A. (2009). Parental divorce and adolescent drunkenness: Role of socioeconomic position, psychological well-being and social support. European Addiction Research, 15, 202-208. doi:10.1159/000231883

U.S. Census Bureau (2012). Statistical abstract of the United States. http://www.census.gov/compendia/statab/overview.html

Wade, T. J., \& Pevalin, D. J. (2004). Marital transitions and mental health. Journal of Health and Social Behavior, 45(2), 155-170. doi:10.1177/ 002214650404500203

Wagner, M., \& Weiß, B. (2006). On the variation of divorce risks in Europe: Findings from a meta-analysis of European longitudinal studies. European Sociological Review, 22(5), 483-500. doi:10.1093/esr/jcl014

Wang, H., \& Amato, P. R. (2000). Predictors of divorce adjustment: Stressors, resources, and definitions. Journal of Marriage and Family, 62(3), 655-668. doi:10.1111/j.1741-3737.2000.00655.x

Wolfinger, N. H. (1999). Trends in the intergenerational transmission of divorce. Demography, 36(3), 415-420. doi:10.2307/2648064

Wolfinger, N. H. (2011). More evidence for trends in the intergenerational transmission of divorce: A completed cohort approach using data from the general social survey. Demography, 48(2), 581-592. doi:10. 1007/s13524-011-0025-4

Wood, R. G., Goesling, B., \& Avellar, S. (2007). The effect of marriage on health: A synthesis of recent research evidence. Washington, D.C: U.S. Department of Health and Human Services.

Yannakoulia, M., Papanikolaou, K., Hatzopoulou, I., Efstathiou, E., Papoutsakis, C., \& Dedoussis, G. V. (2008). Association between family divorce and children's BMI and meal patterns: The GENDAI study. Obesity, 16(6), 1382-1387. doi:10.1038/oby.2008.70

Zimmerman, D. K., Brown, J. H., \& Portes, P. R. (2004). Assessing custodial mother adjustment to divorce: The role of divorce education and family functioning. Journal of Divorce \& Remarriage, 41(1-2), 1-24. doi:10.1300/J087v41n01_01 
DRUŠ, ISTRAŽ ZAGREB GOD. 23 (2014), BR. 1, STR. 5-24

AMATO, P. R.

THE CONSEQUENCES..

\section{Učinci rastave braka na} odrasle i djecu: najnoviji nalazi

Paul R. AMATO

Državno sveučilište u Pennsylvaniji, University Park, PA, SAD

Stopa rastave braka porasla je od 1960. godine i u SAD-u i $u$ većini europskih zemalja. Briga javnosti i znanstvene zajednice o posljedicama rastave i njezinim učincima na odrasle i djecu rezultirala je opsežnom istraživačkom literaturom. U većini studija utvrđeno je da rastavljene odrasle osobe imaju više mentalnih i fizičkih zdravstvenih smetnji nego što to imaju udane / oženjene. Većina studija upućuje i na to da djeca rastavljenih roditelja imaju više mentalnih i fizičkih zdravstvenih problema nego djeca čiji su roditelji stalno u braku. Dostupna istraživanja pokazuju da su ove tvrdnje djelomično lažne (zbog učinaka selekcije), a dijelom i zbog stresa što ga uzrokuje prekid braka. Reakcije ljudi na rastavu vrlo su različite, jer brzina i stupanj prilagodbe ovise o raznim mogućnostima i okolnostima koje nastaju nakon rastave. U Sjedinjenim Američkim Državama postoji nekoliko vrsta sudskih programa, kao i onih unutar lokalne zajednice, koji roditeljima i djeci olakšavaju prilagodbu na rastavu.

Ključne riječi: rastava, odvajanje, mentalno zdravlje, fizičko zdravlje, veličine učinka, odabir, prilagodba na rastavu, druga demografska tranzicija 